\title{
Mjesto, nemjesto. Interdisciplinarna promišljanja prostora i kulture, red. J. Čapo, V. Gulin Zrnić, Biblioteka Etnografija, Zagreb 2011, ss. 444
}

Prezentowany tom został wydany przy współpracy Instytutu Etnologii i Folklorystyki w Zagrzebiu (Institut za etnologiju i folkloristiku) oraz Instytutu Studiów Antropologicznych i Przestrzennych, Centrum Badawczego Słoweńskiej Akademii Nauki i Sztuki w Lublanie (Inštitut za antropološke in prostorske študije, ZRC SAZU). Jest on częścią realizowanego przez IEiF programu badawczego Suvremeni kulturni tijekovi i oblikovanje zajednica $i$ identiteta, finansowanego ze środków chorwackiego Ministerstwa Nauki Oświaty i Sportu w latach 2007-2011.

Publikacja składa się z dwudziestu artykułów autorstwa antropologów kultury, etnologów, geografów, socjologów i przedstawicieli innych dziedzin nauki, którzy w centrum swoich zainteresowań badawczych umieścili kwestie związane z szeroko rozumianą problematyką miejsca i przestrzeni. Poruszanie problematyki dotyczącej wymienionych kategorii implikuje pojawienie się w licznych pracach dyskursu tożsamościowego. Główny korpus tekstów poprzedza obszerny artykuł redaktorek recenzowanego tomu - Jasny Čapo i Valentiny Gulin Zrnić - wprowadzający w tematykę badań nad przestrzenią z perspektywy chorwackiej i światowej etnologii, antropologii kultury i geografii kulturowej. W poszczególnych artykułach zawartych w tomie opisano badania dotyczące między innymi terytoriów spornych i granicznych, przestrzeni transnarodowych oraz, oderwanych od rzeczywistości fizycznej, lokacji wirtualnych. Egzemplifikacją przeprowadzanych badań są liczne przykłady miejsc i przestrzeni znajdujących się na terytorium Chorwacji, Słowenii, Bośni i Hercegowiny, Albanii, a także Australii.

Treść tomu stanowi odzwierciedlenie dominującego we współczesnej humanistyce przekonania, że zajmując się procesami identyfikacji i kształ- 
towania wspólnot, poza klasycznymi pojęciami etnologicznymi i antropologicznymi, takimi jak kultura, wspólnota i tożsamość, uwzględnić należy terminy przestrzeń i miejsce. Poszczególni badacze (w większości pochodzący z Chorwacji, chociaż zdarzają się wyjątki - chociażby autorzy pochodzący z sąsiedniej Słowenii, ale i odległych antypodów) starają się odpowiedzieć na pytania stawiane im przez współczesność, w której, przynajmniej w dyskursie naukowej humanistyki, przestrzeń nie jest już prosta, neutralną siatką wspólrzędnych, lecz esencjonalnym komponentem teorii socjokulturowej. Zgodnie z mottem Edwarda Halla, przytoczonym w artykule wstępnym, miejsce mówi, zatem zadaniem współczesnej humanistyki powinno być uważne wystuchanie tego, co ma ono do powiedzenia, a na podstawie zdobytych w ten sposób informacji, dokonanie naukowej deskrypcji.

Materiał podzielony został według kryterium tematycznego na osiem działów: począwszy od tekstów teoretycznych, nakreślających pole badawcze i miejsce dyskursu przestrzennego w chorwackiej humanistyce, na badaniach konkretnych przestrzeni skończywszy. Tom otwiera wspomniany już artykuł redaktorek zatytułowany Oprostornjavanje antropološkog diskursa. Od metodološkog problema do epistemološkog zaokreta, a po nim następują rozdziały: I. Disciplinarne prizme, II. Povijest i pamćenje, III. Prijeporni prostori, IV. Prostor i moć, V. Javni prostori, VI. Dom, domovina, svijet: umještanje izmještenog, VII. Fizičko u virtualnom: imaginacija i lokacija.

W artykule otwierającym monografię Jasna Čapo i Valentina Gulin Zrnić śledzą proces wzrostu znaczenia kategorii przestrzeni jako przedmiotu refleksji naukowej. Autorki wskazują niezliczoną liczbę pól badawczych dyskursu przestrzennego humanistyki, poprzez zarysowanie niezwykle gęstej siatki relacji łączących ze sobą wspólnoty ludzkie, kreowane przez wieki kultury i oswajane przez człowieka przestrzenie. Badaczki wyliczają chociażby grupy pytań związanych z migracją (relacja migrant - przestrzeń - miejsce - tożsamość), poczuciem tożsamości (relacja tożsamość jednostkowa - tożsamość grupowa - przestrzeń - miejsce), procesami globalizacyjnymi (kultura globalna - kultury regionalne, lokalne) oraz z pojawieniem się w XXI wieku przestrzeni i wspólnot/społeczności oderwanych od fizycznie istniejącej rzeczywistości, a funkcjonujących w świecie cyberprzestrzeni. Pierwsza część artykułu dotyczy egzemplifikacji najpopular- 
niejszych, klasycznych koncepcji kultury i jej relacji z przestrzenią (Prostor kao kontejner kulture). Druga jest wprowadzeniem do rozważań na temat emancypacji miejsca w dyskursie przestrzennym (Afirmiranje mje$s t a)$. W trzeciej części autorki opisują relację kultury z przestrzenią poprzez ukazanie miejsca postrzeganego z perspektywy lokalnej, oddolnej, fenomenologicznej, jak również z pozycji komplementarnych procesów społecznego produkowania i konstruowania przestrzeni (Mjesta i nemjesta: osjećaj mjesta, lokalno i lokalnost). Tematem czwartej części pracy jest kwestia przedkładania nad większe przestrzenie pojedynczego, bliższego podmiotowi oswojonego miejsca, wbrew współczesnym tendencjom globalistycznym. W tym fragmencie badaczki odnoszą się także do pojęć translokalności i transnarodowości oraz poddają badaniu zjawisko społecznego i epistemologicznego pozycjonowania lokacji (Alternativna kartografija prostora i kultura: deteritorizacija, translokalno i politika lokacija). Kolejny segment artykułu wprowadzającego opisuje problematykę przestrzeni ukształtowanych przez nowe, dominujące konteksty lub technologie, które zgodnie z naukowym paradygmatem, ale i życiowym doświadczeniem, stały się częścią naszej codzienności (Hiperprostori, turistička i virtualna mjesta, heterotopije postmodernosti). Ostatnia część artykułu to swoiste podsumowanie omawianych wcześniej pól badawczych chorwackiego i światowego dyskursu przestrzennego (Rastočenost prostora i kompozicija kulture).

$\mathrm{W}$ rozdziale pierwszym omawianej książki zawarte zostały teksty teoretyczne, przedstawiające miejsce, rolę i kształt refleksji nad przestrzenią w poszczególnych dziedzinach współczesnej humanistyki. Valentina Gulin Zrnić w swoim artykule szuka odpowiedzi na pytanie o miejsce przestrzeni w chorwackiej etnologii i antropologii kultury, przedstawiając pola tematyczne i podejścia badawcze, dla których przestrzeń/miejsce jest wyraźnie formułowanym bądź ukrytym przedmiotem analizy lub interpretacji (Prostor i mjesto u hrvatskoj etnologii/kulturnoj antropologiji). Laura Šakaja zajmuje się natomiast fenomenem rozwoju refleksji naukowej nad miejscem w dyskursie geografii humanistycznej. Pierwsza monografia w całości poświęcona miejscu - Place and Placelessness Edwarda Relpha z 1976 roku - staje się fundamentem, na którym autorka artykułu buduje historię zmian ontologicznego i epistemologicznego podejścia do tej jednej z najistotniejszych, również dla geografii humanistycznej, kategorii dyskur- 
su przestrzennego (Mjesto $u$ diskursu humane geografije). Sarah Czerny w swoich rozważaniach analizuje organizację przestrzeni z perspektywy tradycyjnych domów chorwackich zlokalizowanych w większości na północy kraju, co prowadzi do wyciągnięcia wniosków dotyczących kształtu relacji społecznych w makroskali (Double Locations. Considering Scholarly Geographical Positions through the Analytical Optic of Inherited Family Houses). Rozdział pierwszy zamyka tekst Melaniji Belaj opisujący semantyczny rozwój pochodzącego $\mathrm{z}$ języka francuskiego terminu terroir - jego pola semantycznego, ale również konotacji społeczno-kulturowych (Terroir: kako je mjesto postalo kultura. Uz kulturnoantropološko istraživanje obiteljske proizvodnje alkoholnih pića).

Druga część tomu obejmuje dwa teksty: Natašy Gregorič Bon oraz Bojana Mucko. Wektor zainteresowań badaczy skierowany jest ku przeszłości terenów w ciągu wieków zamieszkiwanych i kształtowanych przez człowieka, dzięki czemu przestrzeń staje się swoistym zapisem rozwoju cywilizacji, specyficznym rodzajem palimpsestu. Uwagę naukowców zwraca także problematyka związana z uwarunkowaniami wpływającymi na tzw. pamięć zbiorową. Gregorič Bon przedstawia przeszłość i teraźniejszość multikulturowego miasta i regionu Himara położonego w południowej części dzisiejszej Albanii. Opisuje ona losy przestrzeni, na której przez wieki dochodziło do mieszania się kultur i stref wpływów (greckich, tureckich, albańskich), co, zdaniem autorki, zmieniło fizyczne miejsce w historiograficzny topos (Reconstructing the Past of Himarë/Himara, Southern Albania). Artykuł Bojana Mucko, dotyczy natomiast czytania miasta współczesnego, jest bowiem opisem działalności i analizą wybranych akcji performatywnych naukowo-artystycznej platformy Bilježenje grada/bilježenje vremena grupy intermedialnych artystów Bacači Sjenki z Katariną Pejović i Borisem Bakalem na czele. Badaniu poddany został komunikacyjny segment ich działalności, a mianowicie zjawisko pamięci zbiorowej w relacji z szeroką publicznością obecną na organizowanych spotkaniach, wykładach i dyskusjach. Mowa jest również o specyficznych miejscach pamięci konstruowanych przez artystów poprzez wytworzenie interakcji pomiędzy ich działaniem a miejscem fizycznym, takim jak na przykład gabloty informacyjne zagrzebskiej Kinoteki (Projekt „Bilježenje gradal bilježenje vremena” kao relacijski okvir društvenoga pamćenja). 
Trzeci rozdział poświęcony został przestrzeniom granicznym, niejednorodnym kulturowo i narodowościowo obszarom, w obrębie których często dochodzi do powstania nowej, multikulturowej tożsamości, ale także do eskalacji postaw ksenofobicznych prowadzących do otwartych konfliktów. Katja Jerman z perspektywy antropologicznej interpretacji miejsca przedstawia relacje dwóch sąsiadujących miast przygranicznych - słoweńskiej Novej Goricy oraz włoskiej miejscowości Gorizia w latach 20032007. Swoje zainteresowania badawcze skupia na problemie wytyczenia granicy dwóch miast, ale i dwóch państw oraz percepcji społecznej tego wydarzenia (A Common Square as a Contested Space between Nova Gorica [Slovenia] and Gorica/Gorizia [Italy]). Przedmiotem zainteresowania Sanji Puljar D'Alessio jest natomiast Mostar, miasto, które po wojnie jugosłowiańskiej zostało podzielone fizycznie i symbolicznie na dwie części chorwacką/katolicką i bośniacką/muzułmańską. Badaczka stawia tezę, iż wbrew przemianom demograficznym, urbanizacji, konfliktom politycznym i kulturowym mieszkańcy miasta zachowali swoją specyficzną lokalną tożsamość odróżniającą ich od reszty społeczeństwa Bośni i Hercegowiny (Projekcija simboličkih prostora u sporna mjesta. Mostar). Trzecim opisanym w tym rozdziale miejscem jest bośniackie sanktuarium maryjne - Međugorje. Marijana Belaj przedstawia wstępne wyniki swoich badań terenowych, skupiając się na percepcji tego miejsca przez kilka kategorii osób w nim przebywających. Interesuje ją, jakie znaczenia przypisują sanktuarium pracujący tam ludzie (zarówno świeccy, jak i duchowni), turyści i pielgrzymi. Badaczka stawia pytanie, jak interakcja z poszczególnymi međugorskimi toposami wpływa na tożsamość poszczególnych jednostek (Međugorje kao proces. Specijalizacija iskustava i stvaranje „mjesta”).

Dwa artykuły składające się na treść kolejnego rozdziału dotyczą przestrzeni na pozór różniących się od siebie diametralnie, a jednak mających ze sobą wiele wspólnego. Sanja Đurin na przykładzie chorwackiego zakładu karnego Lepoglava przedstawia specyficzną przestrzeń więzienia, gdzie badała reguły życia więziennego oparte na zasadzie autorytetu siły, prowadzącej do wyraźnego zhierarchizowania więziennej społeczności i wytworzenia się nowej tożsamości osadzonych (Lepoglavski Panaptikon - prostor, moć, identitet). Paradoksalnie argument siły, chociaż w nieco szerszym znaczeniu, okazuje się również kluczowy w przypadku organizacji drugiej opisywanej w tym rozdziale przestrzeni, multikulturowej austra- 
lijskiej metropolii Melbourne. Ian Woodcock i Jan Smitheram, autorzy artykułu, porównują dwie części miasta (Federation Square i Sydney Road), by ukazać różnice dotyczące wyglądu i wytworzonej tożsamości miejscowej obu przestrzeni. Jedną charakteryzują elitaryzm i jednorodność, drugą zaś etniczno-kulturowa heterogeniczność (Relational Place-Identities in Multicultural Melbourne).

Autorzy, których teksty znalazły się w rozdziale piątym, poświęcili uwagę przestrzeniom publicznym i czynnikom powodującym ich nieprzerwaną degradację. Anđelina Svirčić Gotovac, obserwując przemiany zachodzące w zglobalizowanym świecie i rozwój posttradycjonalnego społeczeństwa informacyjnego, zauważa, że niegdyś główni bohaterowie życia publicznego obecnie tracą na znaczeniu, ponieważ ich funkcje przejmują nowe podmioty będące elementami interakcji społecznej. W artykule opisuje regres instytucji i przestrzeni publicznych i progres ich prywatnych, skomercjalizowanych odpowiedników (Aspekti ugroženosti javnih prostora). Nieco szczegółowiej, bo na przykładzie konkretnego miasta - Zagrzebia, problem egzemplifikuje Jelena Zlatar. Powód kurczenia się sfery publicznej, zanikania lub przenoszenia funkcji miejsc publicznych w inne niż tradycyjne przestrzenie miejskie, badaczka widzi w komercjalizacji współczesnej rzeczywistości i pojawieniu się świątyń konsumpcji, jakimi współcześnie stały się centra handlowe (Utjecaj trgovačkih centara [kao nemjesta] u Zagrebu na nestajanje javnog prostora).

Przedostatni, szósty rozdział omawianego tomu dotyczy migracji i zadomowiania przestrzeni dotąd obcych przybyszowi. Temat przymusowego przesiedlenia Chorwatów, ale i przedstawicieli innych nacji z Wojwodiny na początku lat dziewięćdziesiątych oraz ich wysiłki zmierzające do oswojenia nowych, zasiedlanych obszarów porusza Jasna Čapo. Skupia się ona na tradycyjnej konceptualizacji doти jako stabilnego i bezpiecznego centrum ludzkiej egzystencji. Dzięki przeprowadzanym badaniom konfrontuje ten pogląd z wizją domu jako miejsca, gdzie jednostka czuje się najlepiej i najlepiej się rozpoznaje (Dvadeset godina poslije. Stvaranje doma u kontekstu prisilno preseljenih osoba). O migracyjnym doświadczaniu domu pisze również Petar Bagarić w artykule opartym na rozmowie przeprowadzonej z przesiedleńcem z Sarajewa (Dug povratak domu. Migrantsko iskustvo domova, odlazaka i povrataka). Rozdział kończy praca Mojcy Piškor stanowiąca analizę wydawnictw muzycznych Darka Rundeka. Au- 
torka zwraca uwagę między innymi na powracający w jego twórczości motyw statku - przestrzeni - przedmiotu - metafory, wskazując na powiązanie muzyki z przestrzenią oraz na motyw migracji, co łączy jej pracę $\mathrm{z}$ innymi tekstami znajdującymi się $\mathrm{w}$ tej części książki.

Mjesto, nemjesto zamyka rozdział siódmy, na którego zawartość składają się artykuły dotyczące najmłodszej z przestrzeni poddawanej refleksji naukowej - rzeczywistości wirtualnej. Iva Pleše, wychodząc z założenia, że Internet jest obszarem wypełnionym konkretnymi miejscami, lokacjami o nakreślonych granicach i właściwościach miejsc fizycznych, opisuje jedną z takich przestrzeni, a mianowicie forum internetowe (Od virtualnog prostora do Web-mjesta. Web-forumi i fizički lokaliteti). Konkretne miejsce przedstawia Ana-Marija Vukušić. Jest nim forum <imoart.hr>, miejsce wirtualnego spotkania osób związanych z Imotską Krajiną. Na podstawie analizy wirtualnego miejsca spotkań mieszkańców wybranego obszaru geograficznego autorka próbuje dociec, czy przestrzeń wirtualna jest zagrożeniem dla komunikacji interpersonalnej w świecie rzeczywistym (O prožetosti virtualnoga i stvarnoga. Primjer jednog ,lokalnog” webforuma). Przedmiotem analizy kolejnej badaczki - Sonji Leboš jest wirtualna społeczność funkcjonująca w świecie Second Life. Istnienie totalnego świata, będącego odwzorowaniem rzeczywistości w cyberprzestrzeni, w którym tworzy się nową tożsamość i funkcjonuje jak w realnym życiu, stawia, zdaniem Leboš, nowe wyzwania przed nauką (Second Life - potraga za imaginacijom ili potraga za paralelnim identitetom?). Ostatnim artykułem w tomie jest tekst Ratka Cvetnicia i Mladena Klemenčicia opisujący projekt wirtualnego muzeum poświęconego jednej z dzielnic Zagrzebia kultowego dla niektórych kręgów osiedla Trnsko (Virtualni muzej zagrebačkog naselja Trnsko).

Jak wynika z przeglądu treści zawartych w tomie Mjesto nemjesto. Interdisciplinarna promišljanja prostora $i$ kulture, monografia jest interdyscyplinarnym kompendium wiedzy na temat współczesnej refleksji naukowej nad przestrzenią i miejscem, kategoriami, które stały się w XXI wieku niezwykle istotne dla badań humanistycznych. W tomie znalazły się zarówno prace o charakterze ogólnym, przedstawiającym czytelnikowi obecnie najpopularniejsze teorie i kierunki badań nad przestrzenią, jak i artykuły dotyczące konkretnych, lokalnych kwestii, miejsc i obszarów. Lektura spisu treści zapowiada, a analiza poszczególnych artykułów za- 
wartych w książce potwierdza, że chorwacka, słoweńska i australijska antropologia, etnologia i geografia kulturowa w dyskursie przestrzennym podążają tymi samymi szlakami co nauka światowa (żeby wspomnieć tylko prace Akhila Gupty i Zygmunta Baumana). Naukowcy na całym globie zajmują się przestrzeniami granicznymi, transformacją przestrzeni publicznych i prywatnych oraz podejmują wyzwanie rzucone przez galopującą cybernetyzację rzeczywistości.

Na szczególne zainteresowanie zasługują, według mnie, artykuły składające się na treść rozdziału VI, poruszające temat przymusowej migracji, uchodźców wojennych i ich wysiłków zmierzających do przekształcenia obcych przestrzeni w nowy dom. Między innymi dzięki tym fragmentom monografia charakteryzuje się dużą wartością poznawczą, a poszczególne zawarte w niej artykuły mogą inspirować do kolejnych refleksji i badań. Uzasadnione jest stwierdzenie, że większość autorów rzetelnie wywiązała się z opracowania zadanego tematu, niewątpliwie uważnie wsłuchując się w to, co mówi miejsce.

Ernest Miedzielski 